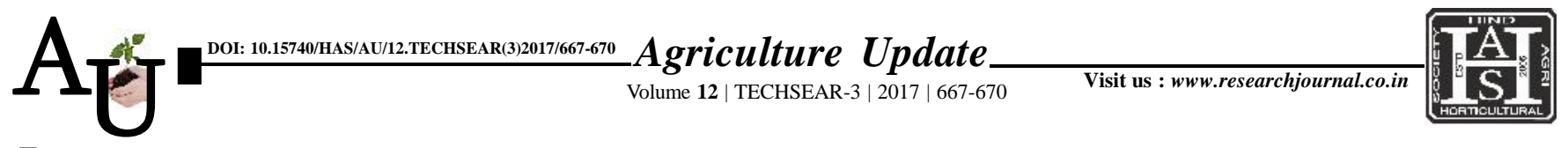

a ISSN-0976-6847

\title{
Research article: Quality assessment of different muskmelon varieties by chemical and sensory analysis
}

\author{
P. SUSHMITHA, B. SRINIVASULU, M. PARATPARA RAO, A.DEVI PRIYA \\ AND M.L. NARAYANA REDDY
}

Article Chronicle:

SUMMARY : A field experiment was conducted on muskmelon varieties for the assessment of qualitative Received :

10.07.2017; traits (TSS, total sugars acidity, aroma, sweetness, flavour and appearance of fruit).High TSS content was observed in the varieties viz., Kanpur (12.03 ${ }^{\circ}$ Brix), Alpur (11.33 ${ }^{\circ}$ Brix), Arka Jeet (11.11 ${ }^{\circ}$ Brix), Pusa Accepted : 25.07.2017

KeY Words:

Muskmelon, Alpur, Arka Jeet, Pusa Maduras Madhuras $\left(10.46^{\circ}\right.$ Brix $)$ and Siddavatam Dosa $\left(10.00^{\circ}\right.$ Brix). The total sugars was high inthe varieties viz., Kanpur, Alpur, Arka Jeet, Pusa Maduras and Siddavatam Dosa $(15.58 \%, 15.02 \%, 14.40 \%, 13.26 \%$ and $12.35 \%$, respectively). Low acidity was recorded in the varieties, Kanpur (0.06\%) and Alpur (0.08 $\%$ ).The muskmelon varieties viz., Bathesa, Kanpur, Pusa Madhuraswere adjudged best in terms of aroma (2.6, 2.3 and 2.1,respectively). The varieties, Alpur, Kanpur, Pusa Madhuras, Arka Jeet, Siddavatam Dosa were identified best in terms of sweetness (3.0, 3.0, 2.8, 2.6 and 2.5, respectively). The varieties, Bathesa, Alpur, Kanpur, Siddavatam Dosa, Pusa Madhuras were observed good interms of flavour (3.4, $3.3,3.1,3.0$ and 2.8,respectively) based on ratings developed through organoleptic test.

How to cite this article : Sushmitha, P., Srinivasulu, B., Rao, M. Paratpara, Priya, A.Devi and Reddy, M.L. Narayana (2017). Quality assessment of different muskmelon varieties by chemical and sensory analysis. Agric. Update, 12(TECHSEAR-3) : 667-670; DOI: 10.15740/HAS/AU/12.TECHSEAR(3)2017/667-670.

\section{P. SUSHMITHA}

Department of Vegetable Science, Horticultural College and Research Institute (Dr. Y.S.R.

Horticultural

University, , ANANTHARAJUPET (A.P.) INDIA

Email : panayamsusi@ gmail.com

See end of the article for authors' affiliations 